\title{
Long-term objective results of proximal phalanx fracture treatment
}

\section{Proksimal falanks kırığı tedavisinin geç dönem objektif sonuçları}

\author{
Derya ÖZÇELIK, Gaye TOPLU, Toygar ÜNVEREN, Fatma KAÇAĞAN, \\ Cemal Tahsin Gökhür ŞENYUVA
}

\section{BACKGROUND}

Proximal phalanx fractures are common. In this study, our preferred methods regarding the treatment of proximal phalanx fractures and their long-term objective results are presented.

\section{METHODS}

Between October 2001 and March 2010, in the Plastic Reconstructive and Aesthetic Surgery Department of Düzce Medical Faculty, we treated 23 patients with 32 proximal phalanx fractures. Stable fractures $(n=5)$ were treated with splints, while unstable fractures $(n=27)$ were stabilized with $1.0 \mathrm{~mm}$ percutaneous intramedullary Kirschner wires following open reduction.

\section{RESULTS}

At follow-ups, ranging from 3 months to 9 years, patients were evaluated with radiologic efficiency, range of motion (ROM), total active movements (TAM), and grip power of the digit. TAM scores of 20 fingers were perfect $\left(\geq 220^{\circ}\right.$ for D2-5, $\geq 150^{\circ}$ for D1), for 7 fingers were good (180$220^{\circ}$ for D2-5, $120-150^{\circ}$ for D1), and for 5 fingers were either moderate or poor. No difference was observed between grip strength of broken fingers and that of healthy fingers. As a major complication, non-union occurred in one finger.

\section{CONCLUSION}

We concluded that Kirschner wire fixation is a reliable and simple method of treating unstable proximal phalangeal fractures, and excellent long-term results can be obtained in suitable cases. In stable proximal phalanx fractures, splints provide sufficient treatment.

Key Words: Fracture; hand; Kirschner wire; proximal phalanx.

\section{AMAÇ}

Proksimal falanks kırıkları sık görülmektedir. Bu çalışmada proksimal falanks kırıklarının tedavisinde tercih ettiğimiz yöntemler ve geç dönem objektif sonuçları sunuldu.

\section{GEREÇ VE YÖNTEM}

Ekim 2001 ve Mart 2010 tarihleri arasında Düzce Tip Fakültesi Plastik Rekonstrüktif ve Estetik Cerrahi Bölümü'nde, 23 hastanın 32 proksimal falanks kırığı tedavi edildi. Stabil kırıklar $(\mathrm{n}=5)$ atel ile takip edilirken stabil olmayan kırıklar $(\mathrm{n}=27)$ açı redüksiyon sonrası 1,0 mm çaplı perkütan intramedüller Kirschner telleri ile tespit edildi.

\section{BULGULAR}

Üç ay ile 9 yıl arasında değişen takiplerde, hastalar redüksiyonun radyolojik yeterliliği, parmağın eklem hareket aralı$\breve{g}_{1}$ (EHA), parmağın total aktif hareketi (TAH) ve parmağın kavrama gücü açısından değerlendirildi. Hastaların 20'sinde redüksiyonun iyi sağlandığı gözlendi. TAH skoru, 20 parmakta mükemmel (D2-5 için $\geq 220^{\circ}$, D1 için $\left.\geq 150^{\circ}\right), 7$ parmakta iyi (D2-5 için $180-220^{\circ}$, D1 için $120-150^{\circ}$ ) ve 5 parmakta orta veya kötüydü. Kırık parmakların kavrama gücü sağlam parmaklarla karşılaştırıldığında fark olmadığı gözlendi. Majör komplikasyon olarak 1 proksimal falanksta non-union gözlendi.

\section{SONUÇ}

Sonuç olarak, Kirschner teli ile tespit yöntemi anstabil k1rıkların tedavisinde güvenilir ve teknik açıdan basit bir yöntemdir. Uygun olgularda çok iyi geç dönem sonuçları elde edilmektedir. Stabil proksimal falanks kırıklarında ise alçı atel ile tespit yeterli tedaviyi sağlamaktadır.

Anahtar Sözcükler: Kırık; el; Kirschner teli; proksimal falanks. 
The most common fractures in the skeleton occur in the small tubular bones of the hands and feet. ${ }^{[1]}$ Of these, fractures of the phalanges are seen most frequently. ${ }^{[1]}$ Distal phalanx fractures are the most common among phalangeal fractures, followed by proximal phalanx (PP) fractures. ${ }^{[1,2]}$ Fractures of the PP are twice as common as fractures of the middle phalanx. ${ }^{[1]}$

Between October 2001- March 2010, 69 patients with 88 hand fractures (distal phalanx, middle phalanx, PP and metacarpal fractures) were treated in our clinic. The distribution of the fractures was as follows: 21 distal phalanx, 21 middle phalanx, $32 \mathrm{PP}$, and 14 metacarpal fractures. Although metacarpal and phalanx fractures are common, the literature on this subject is lacking. We designed this prospective study to evaluate the treatments and long-term results of PP fractures, which is the most common hand fracture seen in our clinic.

To diagnose PP fractures effectively, the mechanism and the force of the trauma should be queried in the initial examination. In the examination, after careful inspection, identification of the most painful area should be done by palpation. Additionally, active and passive ranges of motion (ROM) of the joints, existence of a possible capsule and ligament instability and associated tendon, neurovascular and soft tissue injuries should be searched. The stability of the joint can be assessed with the stress test performed while the finger is in flexion and extension. In X-ray examination, three views are essential: anteroposterior, lateral and $45^{\circ}$ oblique. Articular fractures are often not seen without the oblique views. ${ }^{[1,3,4]}$

Anatomically, PP fractures can be divided into four categories, including condyle, neck, shaft, and base. Other parameters important for PP fractures are:

1. Displacement of the fracture

2. Stability of the fracture

3. Involvement of the joints

4. Type of the fracture, such as oblique, spiral, transverse or comminuted

5. Associated soft tissue injury (tendon, nerve, artery, skin...)

Stable and nondisplaced PP fractures can be effectively managed by protective splinting and early controlled mobilization. Although three weeks of immobilization is accepted as safe, ${ }^{[3]}$ each patient and fracture type has its own characteristics. Each fracture, therefore, should be assessed individually.

Unstable and nondisplaced PP fractures should be managed with fixation. PP fractures may angulate volarly or dorsally due to localization of the fracture and interactions with the tendons and interosseous and lumbrical muscles. Angulated fractures are considered as unstable and require open reduction and fixation.
Nondisplaced intraarticular PP fractures are highly unstable and susceptible to displacement. Those fractures are occasionally misdiagnosed as sprain, and early mobilization may cause their displacement.

Bicondylar fractures are almost always multiple fractures and require open reduction as with unicondylar fracture treatment. Multiple fractures in proximal interphalangeal (PIP) joints are known as pilon fractures. ${ }^{[3]}$ If open reduction and fixation is not possible in such multiple fracture cases, traction-closed reduction or dynamic external fixation devices can be options. Restoration of movement is usually unpredictable in such cases. Primary arthrodesis or osteosynthesis applications may cause unexpected results, such as excessive shortening of the finger. Since arthrodesis is already possible as a secondary procedure, restoration of the primary structure should be preferential. Dynamic external fixation devices are hinged and span the PIP joint to allow early protected ROM while maintaining reduction of the joint. ${ }^{[3]}$

There is a consensus about treating displaced PP fractures with open reduction and internal fixation. Present lacerations secondary to injury can be used for access to the fracture line. Dorsal incision is usually preferred when the fracture is not adequately exposed. The fracture line is exposed without damaging the connections of the central slip of the extensor tendon. Ligamentous and soft tissue attachments of the fracture fragments should be preserved, if possible. Fracture lines are fixated with one or multiple Kirschner wires (K-wire) or screws. Generally, $1 \mathrm{~mm}$ or $1.2 \mathrm{~mm}$ $\mathrm{K}$-wires will serve. Sometimes K-wires and screws can be used together. When placing the splint, the PIP joints are held in nearly full extension to prevent the collateral ligament and volar plate contracture that occurs in flexion. Other soft tissue injuries are repaired after fixation of the fracture. The K-wire is removed 3-6 weeks postoperatively and the mobilization starts under the observation of a physiotherapist.

In this article, we present our choice of treatments and the long-term objective results of our patients with PP fractures.

\section{MATERIALS AND METHODS}

Between October 2001 and March 2010, in the Plastic Reconstructive and Aesthetic Surgery Department of Düzce Medical Faculty, we treated 23 consecutive patients with 32 PP fractures. Here, the treatment choices and results are presented.

Seventeen male and 6 female patients were included. The ages of the patients ranged from 5 to 78 years (mean: 41). Two patients were under the age of 16 (5 and 8 years old); the other 21 patients were over 16 years. 


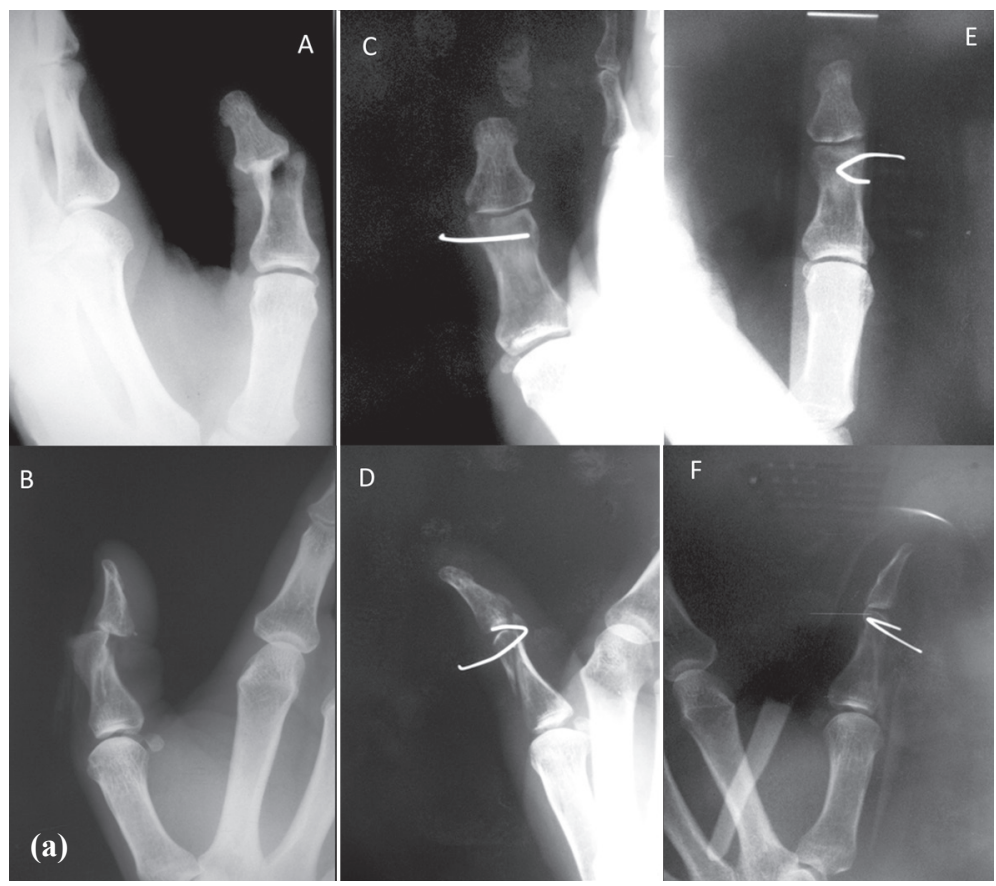

Fig. 1. (a) Unstable, displaced proximal phalanx shaft fracture extending to the IP joint with dislocation of the IP joint in the left hand 1st finger. Fracture was treated with a transverse K-wire. Extensor pollicis longus tendon injury was also repaired. A-B: Preoperative anteroposterior and lateral X-ray views. C-D-E-F: Postoperative anteroposterior, lateral and oblique $\mathrm{X}$-ray views.

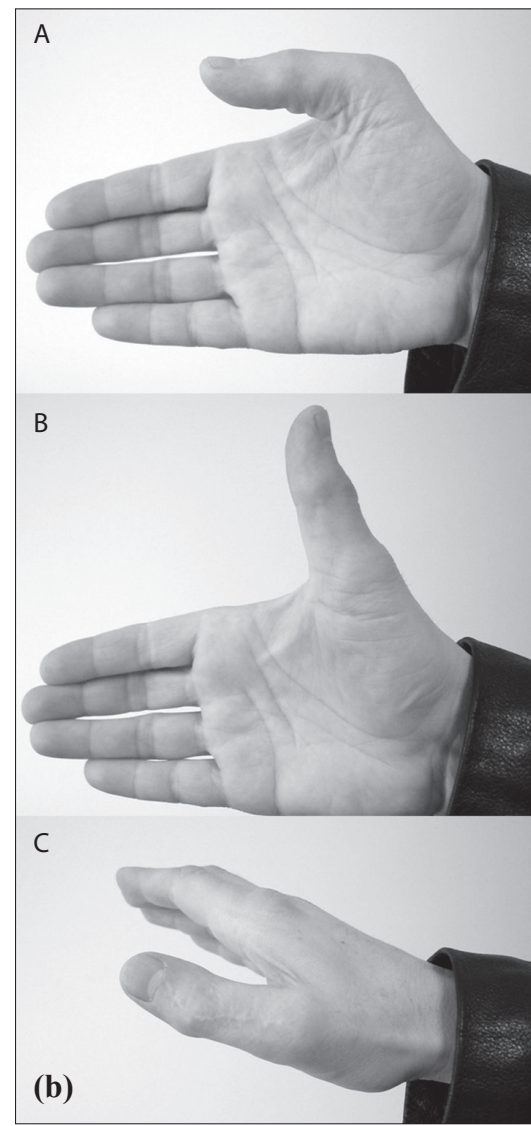

(b)

(b) Functional results of the patient with unstable, displaced proximal phalanx shaft fracture extending to the IP joint with dislocation of the IP joint in the left hand 1st finger. A-B: No flexion or extension deficit was observed in the postoperative 2nd year. C: Dorsal view.

Regarding the etiology, work-related accidents $(56 \%)$ were the most common cause, followed by home accidents (21\%). Six patients (26\%) suffered from right hand injury and 17 patients (74\%) from left hand injury. The first and second fingers were the most commonly injured. Of 32 fractures, seven were observed at the first finger and seven at the second finger; the rest of the fractures were distributed among the other fingers.

Ten $(31 \%)$ of the 32 fractures were intraarticular and $22(69 \%)$ were extraarticular. One patient had a fracture line extending between the PIP and metacarpophalangeal (MCP) joints.

Eleven patients had associated metacarpal or middle or distal phalangeal fractures. The most common fracture associated with PP fractures was distal phalanx fracture (4 distal phalanx fractures accompanied $32 \mathrm{PP}$ fractures) (13\%). Metacarpal fracture was the second most common fracture associated with PP fractures (3 metacarpal fractures accompanied 32 PP fractures). The most common soft tissue injury associated with PP fractures was extensor tendon injury (15 extensor tendon injuries in 32 PP fractures) (34\%) (Fig. 1a-b). Other soft tissue injuries associated with PP fractures were flexor tendon, digital artery and digital nerve in- juries, and skin defects, which require reconstruction with a flap or a graft. The extent of comminution of PP fractures did not preclude the use of K-wires in any of the patients in this study.

Eight patients were operated under general anesthesia and 15 under digital or axillary block. Twentyseven of 32 fractures were unstable and treated with open reduction, K-wire fixation and splinting. Five of the 32 fractures were treated with closed reduction and splint application.

Fixations were achieved with $1 \mathrm{~mm}$ percutaneous intramedullary K-wires. Two K-wires were used for fixation when one K-wire did not provide enough stability (Fig. 2a-b). When possible, the proximal and distal interphalangeal (DIP) joints were held in nearly full extension during the fixation to prevent the collateral ligament and volar plate contracture. A splint was used for all patients and elevation was recommended. Postoperatively, follow-up radiographs were taken immediately to verify adequate reduction. If there was a suspicion of inadequate reduction during the operation, intraoperative scopy was used. Usually, empiric oral sulbactam-ampicillin treatment was administered postoperatively. 


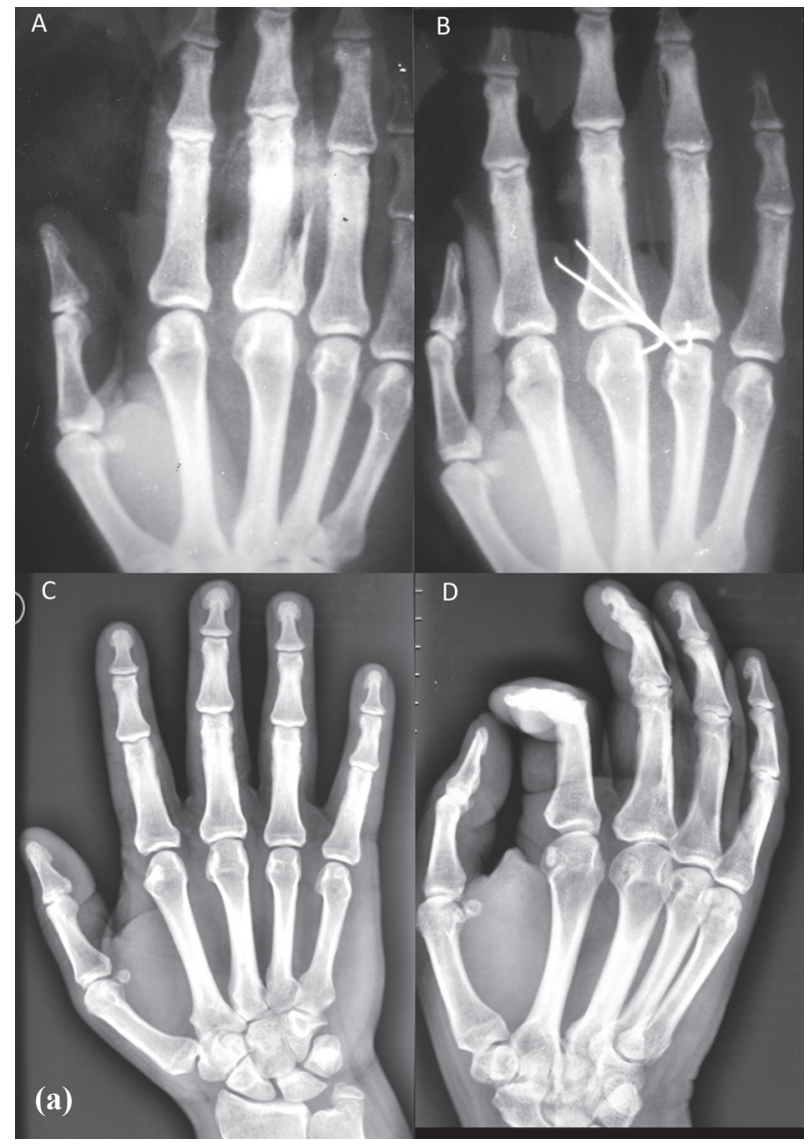

Since joint stiffness occurs after a three-week immobilization period, K-wires are removed at the end of the 3rd week. ${ }^{[3]}$ Radiographs are also used for evaluation of bone healing in the postoperative 3rd week. The removal of the $\mathrm{K}$-wire is delayed if adequate bone healing is not observed in the follow-up radiographs. In our series, K-wires were removed between 4-6 weeks. Then, Coban ${ }^{\circledR}$ bandage was applied to the fingers to control edema. Physiotherapy was started just after the removal of the K-wires.

In the long-term evaluations, the following parameters were considered:

\section{Total active movement (TAM);}

2. PIP or IP joint and MCP joint ROM;

3. The function of the hand and the injured finger (grip strength).

Table 1. Grading for range of motion results

\begin{tabular}{lcccccc}
\hline & MCP & PIP & IP & MCP & PIP & IP \\
\hline Perfect & $60-85^{\circ}$ & $90-110^{\circ}$ & $60-90^{\circ}$ & 29 & 15 & 7 \\
Good & $40-60^{\circ}$ & $60-90^{\circ}$ & $40-60^{\circ}$ & 1 & 5 & 0 \\
Moderate & $20-40^{\circ}$ & $30-60^{\circ}$ & $20-40^{\circ}$ & 0 & 1 & 0 \\
Poor & $0-20^{\circ}$ & $0-30^{\circ}$ & $0-20^{\circ}$ & 2 & 4 & 0 \\
Total & & & & 32 & 25 & 7 \\
\hline
\end{tabular}

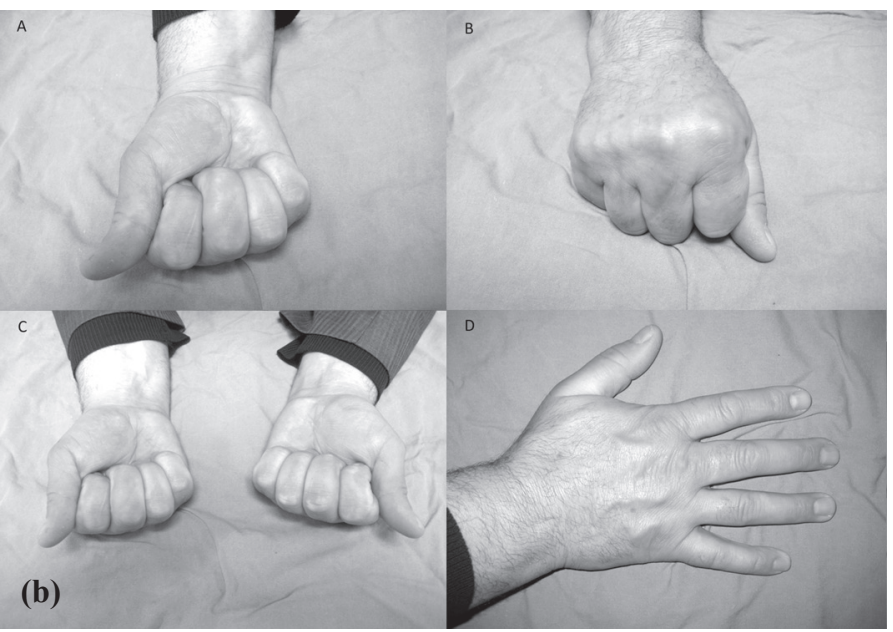

Fig. 2 (a) Unstable, displaced oblique proximal phalanx shaft fracture extending to the MCP joint in the right hand 3rd finger was treated with 2 oblique K-wires. Excellent bone healing was observed in the postoperative 8th year. A: Preoperative $\mathrm{X}$-ray views. B: Early postoperative X-ray views. C-D: Late postoperative X-ray views. (b) Functional results of the patient with unstable, displaced proximal phalanx shaft fracture extending to the MCP joint in the right hand 3rd finger in the postoperative 8 th year. A-B: ROM of the fractured finger showed no difference from healthy fingers. C: The grip strength of the broken finger was compared with that of healthy fingers and no difference was observed. D: No extension deficit was observed in the postoperative 8 th year.

1. Total active movement: TAM can be calculated by sum of the angles formed by MCP, PIP and DIP joints in maximum active flexion, minus total extension deficit at the MCP, PIP and DIP joints during active finger extension. In a normal finger flexion, the MCP joint can flex up to $85^{\circ}$, PIP joint can flex up to $110^{\circ}$ and the DIP joint can flex up to $65^{\circ}$. If the finger is capable of full extension, the loss of extension is calculated as $0^{\circ}$. As a result, TAM is measured as $260^{\circ}$ $\left(260^{\circ}-0^{\circ}: 260^{\circ}\right)$.

In a normal first finger, the MCP joint can flex up to $85^{\circ}$ and the IP joint can flex up to $90^{\circ}$, and as a result, TAM is measured as $175^{\circ}$.

2. In all 32 fingers, for two adjacent joints including MCP and/or PIP-IP, ROM values were measured. We designed a grading system for ROM of the PIP joint as: $0-30^{\circ}$ poor, $30-60^{\circ}$ moderate, $60-90^{\circ}$ good, and 90 $110^{\circ}$ perfect. The grading system for the ROM of the IP joint of the first finger was: $0-20^{\circ}$ poor, $20-40^{\circ}$ moderate, $40-60^{\circ}$ good, and $60-90^{\circ}$ perfect (Table 1 ).

3 . In the grading system for ROM of the MCP joint of all fingers, we considered $0-20^{\circ}$ as poor, $20-40^{\circ}$ as moderate, $40-60^{\circ}$ as good, and $60-85^{\circ}$ as perfect (Table 1 ).

4. In the long-term follow-ups, the grip strength of the broken fingers was compared with that of healthy fingers. 
Table 2. Mean total active movement values in all proximal phalanx fractures (n: 32)

\begin{tabular}{lcc}
\hline & TAM & Normal value \\
\hline D1 $(n=7)$ & $156^{\circ}$ & $175^{\circ}$ \\
D2-3-4-5 $(n=25)$ & $205.5^{\circ}$ & $260^{\circ}$ \\
\hline
\end{tabular}

Table 3. Grading of total active movement results

\begin{tabular}{lccc}
\hline & $\begin{array}{c}\text { D1 grading } \\
\text { values }\end{array}$ & $\begin{array}{c}\text { D2-3-4-5 grading } \\
\text { values }\end{array}$ & $\begin{array}{c}\text { Phalanx } \\
\text { number }\end{array}$ \\
\hline Perfect & $150-175^{\circ}$ & $220-260^{\circ}$ & 20 \\
Good & $120-150^{\circ}$ & $180-220^{\circ}$ & 7 \\
Moderate & $90-120^{\circ}$ & $150-180^{\circ}$ & 1 \\
Poor & $0-90^{\circ}$ & $0-150^{\circ}$ & 4 \\
Total & & & 32 \\
\hline
\end{tabular}

Table 4. Mean range of motion values for all proximal phalanx fractures (n: 32)

\begin{tabular}{lccc}
\hline & MCP & PIP & IP \\
\hline D1 $(n=7)$ & $74^{\circ}$ & - & $82.5^{\circ}$ \\
D2-3-4-5 $(n=25)$ & $71^{\circ}$ & $87^{\circ}$ & - \\
D1-2-3-4-5 $(n=32)$ & $72^{\circ}$ & - & - \\
Normal & $85^{\circ}$ & $110^{\circ}$ & $90^{\circ}$ \\
\hline
\end{tabular}

Table 5. Mean range of motion values for intraarticular proximal phalanx fractures (n: 10)

\begin{tabular}{lccc}
\hline & MCP & PIP & IP \\
\hline D1 $(n=5)$ & $62.5^{\circ}(n=2)$ & - & $75^{\circ}(n=3)$ \\
D2-3-4-5 $(n=5)$ & $77^{\circ}(n=3)$ & $70^{\circ}\left(n=3^{*}\right)$ & - \\
D1-2-3-4-5 $(n=10)$ & $71^{\circ}(n=5)$ & $70^{\circ}\left(n=3^{*}\right)$ & $75^{\circ}(n=3)$ \\
Normal & $85^{\circ}$ & $110^{\circ}$ & $90^{\circ}$ \\
\hline
\end{tabular}

* One patient had a fracture line extending between the proximal interphalangeal and metacarpophalangeal joints, which was counted twice.

Table 6. Mean range of motion values for extraarticular proximal phalanx fractures (n: 22)

\begin{tabular}{lccc}
\hline & MCP & PIP & IP \\
\hline D1 & $77.5^{\circ}(\mathrm{n}=5)$ & - & $87.5^{\circ}(\mathrm{n}=4)$ \\
D2-3-4-5 & $70.5^{\circ}(\mathrm{n}=22)$ & $90^{\circ}(\mathrm{n}=22)$ & - \\
D1-2-3-4-5 & $71^{\circ}(\mathrm{n}=27)$ & - & - \\
Normal & $85^{\circ}$ & $110^{\circ}$ & $90^{\circ}$ \\
\hline
\end{tabular}

\section{RESULTS}

Follow-up periods of patients ranged from 3 months to 9 years. In the follow-ups, we evaluated radiological efficiency of reduction, TAM of the finger, ROM of the joints, and the grip strength of the finger.

Immediately after the surgery, radiological efficiency of reduction was determined. When inadequate or poor reduction was present, reduction and fixation were repeated.
The mean time for radiological bone healing was 6 weeks ( 4 - 8 weeks). The mean time for complete bone union in fracture lines was approximately 4 months.

Except for one patient with associated radius-ulna fractures, all patients were discharged from the hospital on the same day of the operation. After bone healing was completed, K-wires were removed in an outpatient setting and controlled mobilization started immediately. No infection was observed in any of the cases.

\section{1- Total active movement (TAM) measurements:}

a) The mean TAM score of $25 \mathrm{PP}$ fractures in the 2nd, 3rd, 4th, and 5th fingers was $205.5^{\circ}$ (Normal: $260^{\circ}$ ) (Table 2).

b) The mean TAM score of 7 PP fractures in the 1st finger was $156^{\circ}$ (Normal: $175^{\circ}$ ) (Table 2).

The TAM scores of 32 PP fractures were calculated, and it was observed that 20 fingers $(63 \%)$ had perfect, 7 fingers (22\%) good, 1 finger (3\%) moderate and 4 fingers $(12 \%)$ poor results (Table 3 ).

\section{2- ROM value of PIP (or IP) and MCP joints:}

a) $\mathrm{ROM}$ of MCP joint (Normal: $85^{\circ}$ for all fingers) $(\mathrm{n}=32)$

Mean ROM for MCP joints in 32 fingers was $72^{\circ}$ (Mean ROM for MCP joints with PP fractures of $1 \mathrm{st}$ finger was $74 \%$, mean ROM for MCP joints with PP fractures of other fingers was 71\%) (Table 4).

Intraarticular PP fractures extending into the MCP joint was observed in 5 out of 32 fingers (Table 5). Two of these 5 fractures were in the 1st finger and 3 of them were in other fingers. Mean ROM for $2 \mathrm{MCP}$ joint intraarticular PP fractures of the 1st finger was $62.5^{\circ}$. Mean ROM for $3 \mathrm{MCP}$ joint intraarticular PP fractures of other fingers was $77^{\circ}$. Mean ROM of these 5 fingers was $71^{\circ}$ (Table 5).

Mean ROM of 27 MCP joint extraarticular PP fractures of all fingers was also $71^{\circ}$.

b) ROM of PIP joint (Normal: $110^{\circ}$ for $2 \mathrm{nd}, 3 \mathrm{rd}$, 4 th and 5th fingers) $(n=25)$

Mean ROM for PIP joints in 25 fingers was $87^{\circ}$ (Table 4).

Three intraarticular PP fractures extending into the PIP joint was observed in 25 fingers. Mean ROM for PIP joints in these 3 fractures was $70^{\circ}$ (Table 5).

Mean ROM for PIP joints in extraarticular fractures $(n=22)$ was $90^{\circ}$ (Table 6). $(\mathrm{n}=7)$

c) ROM for IP joint (Normal: $90^{\circ}$ - for 1 st finger)

Mean ROM for IP joints in 7 fingers was $82.5^{\circ}$ (Table 4). 
Mean ROM for 3 intraarticular PP fractures extending into the IP joint was $75^{\circ}$ (Table 5). Mean ROM for IP joints in 4 extraarticular fractures was $87.5^{\circ}$ (Table 6).

ROMs of 29 fingers (91\%) for MCP joint, 15 fingers $(47 \%)$ for PIP joint and 7 fingers $(100 \%)$ for IP joint were calculated as perfect (Table 1).

\section{Function of the hand and the injured finger (grip} strength):

In long-term follow-ups, the grip strength of the broken fingers was compared with that of healthy fingers and no difference was observed.

In our study, nonunion occurred in 1 patient. Bone ends were debrided again, and fixation was re-achieved with K-wire. Complete bone healing was achieved in the follow-up. Angulations occurred in 2 patients but did not interfere with the normal function of the finger. There was no pain on fracture lines. Arthrodesis was applied in 2 patients having intraarticular PP fractures extending into the PIP joint. Cases with arthrodesis were excluded from the average ROM calculation.

All patients were satisfied with the results.

\section{DISCUSSION}

In our cases, we observed that PP fractures are the commonest among the phalanx and metacarpal fractures. This can be explained by the type of injury, which was mostly open unstable fracture complicated with soft tissue injury such as tendon, nerve or artery injury or skin loss. This is likely why patients were referred to our University Hospital. The simpler cases are probably treated in local centers successfully.

Treatment of PP fractures is based on the presentation of the fracture, degree of displacement and difficulty in maintaining fracture reduction. A wide array of treatment options exists for the variation in fracture patterns observed. Inherently stable fractures do not require surgical treatment; all other fractures should be considered for additional stabilization. In general, many combinations of internal fixation are possible; $\mathrm{K}$-wires and screw-and-plate fixation predominate. Plate fixation is used in comminuted PP and lag screws in spiral long oblique phalanx shaft fractures. ${ }^{[5]}$

Although successful results were reported regarding screw-and-plate fixation in different studies,${ }^{[6]}$ we use screw-and-plate fixation in metacarpal fractures in a limited number. We observed that the plate and screw present some disadvantages such as the requirement of extensive dissection over the phalanx or metacarpal, formation of a large bulk under the tendon and the possibility of inadequate stabilization using microplates. Additionally, in some cases, we observed extrusion of the screws (Fig. 3). Kurzen et al. ${ }^{[6]}$ assessed the complications after plate fixation of 64 phalangeal fractures in 54 consecutive patients and their outcome. Among the complications, stiffness (TAM $<180^{\circ}$ ) contributed the highest number (22 patients, 24 fractures). In spite of early mobilization, stiffness is the most frequent complication after open reduction and plate fixation of phalangeal fractures. The authors thought that the undue amount of scarring and adhesion may arise from the implant itself or the difficulty in finding the perfect mixture between the minimal surgical

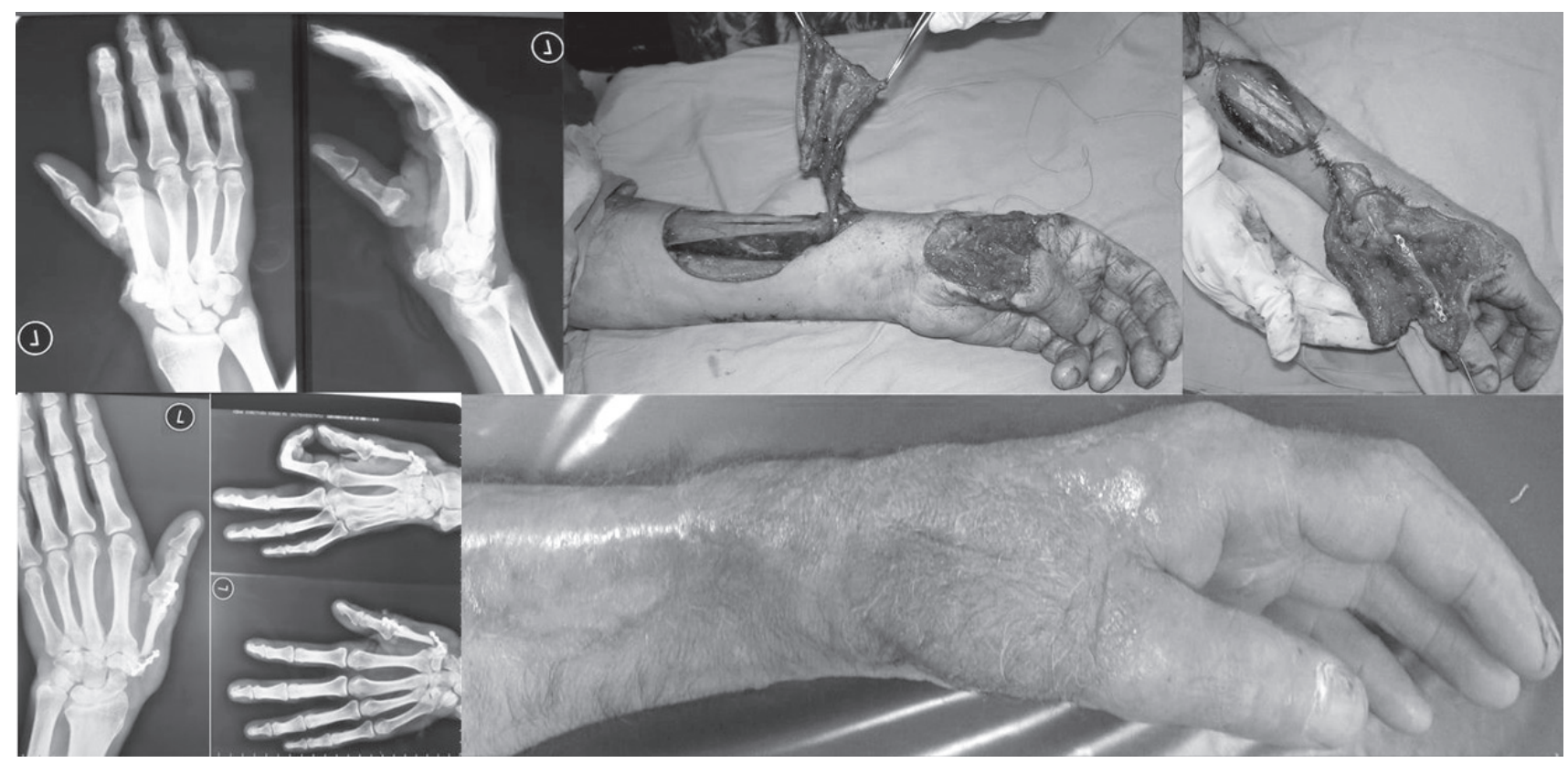

Fig. 3. Traumatic absence of the first metacarpal bone was reconstructed with the radial osteocutaneous pedicled flap and fixation was provided with the plate-screw. Postoperatively, extrusion of the screws was observed. 
invasiveness and a sufficient restoration of skeletal stability. Otherwise, they found that plate fixation of unstable and complex phalangeal fractures provided efficient and reliable results.

Al-Qattan et al. ${ }^{[7]}$ reported 78 male workers with displaced unstable transverse fractures of the PP shaft. They divided the patients into two groups according to the treatment applied. Group $1(\mathrm{n}=40)$ was treated with closed reduction and percutaneous K-wires, and Group $2(n=38)$ was treated with open reduction and interosseous loop wire fixation. At the final follow-up, Group 2 had significantly better overall TAM scores than Group $1(\mathrm{p}=0.03)$. The complication rate was higher in Group 1 than Group 2 (28\% versus 11\%), but the difference did not reach statistical significance $(\mathrm{p}=0.084)$.

Sorene et al. ${ }^{[8]}$ reported a retrospective study of the non-operative treatment of displaced avulsion fractures of the ulnar base of the PP of the thumb. The study included 28 thumbs that were stable to lateral stress testing at the time of the initial investigation. The patients were treated by immobilization of the thumb in a spica cast. The mean follow-up interval was 2.5 years. Twenty-six patients $(93 \%)$ reported no pain on movement of the thumb. Grip and pinch strengths did not differ significantly on the injured and non-injured sides. No thumbs showed instability on stress testing. Non-operative treatment is recommended in cases of displaced or rotated avulsion fractures provided that there is no lateral instability of the MCP joint. They stressed that patients with unstable thumbs should always be treated surgically.

Horton et al. ${ }^{[9]}$ randomly divided patients with an isolated spiral or long oblique fracture of the PP into two groups. One group was treated by closed reduction and K-wire fixation and the second by open reduction and lag screw fixation. An independent observer assessed function, pain, movement, grip strength, and intrinsic muscle function. Thirty-two patients were entered into the study, and 15 in the K-wire and 13 in the lag screw group were reviewed at a mean follow-up of 40 months. There was no significant difference in the functional recovery rates or in the pain scores for the two groups. X-rays showed similar rates of malunion, and there were no statistically significant differences in ROM or grip strength.

Elmaraghy et al. ${ }^{[10]}$ presented a retrospective review of 35 digits in 24 patients with unstable fractures of the PP treated using the technique of percutaneous transmetacarpal intramedullary K-wire fixation. Outcome measures, including radiological adequacy
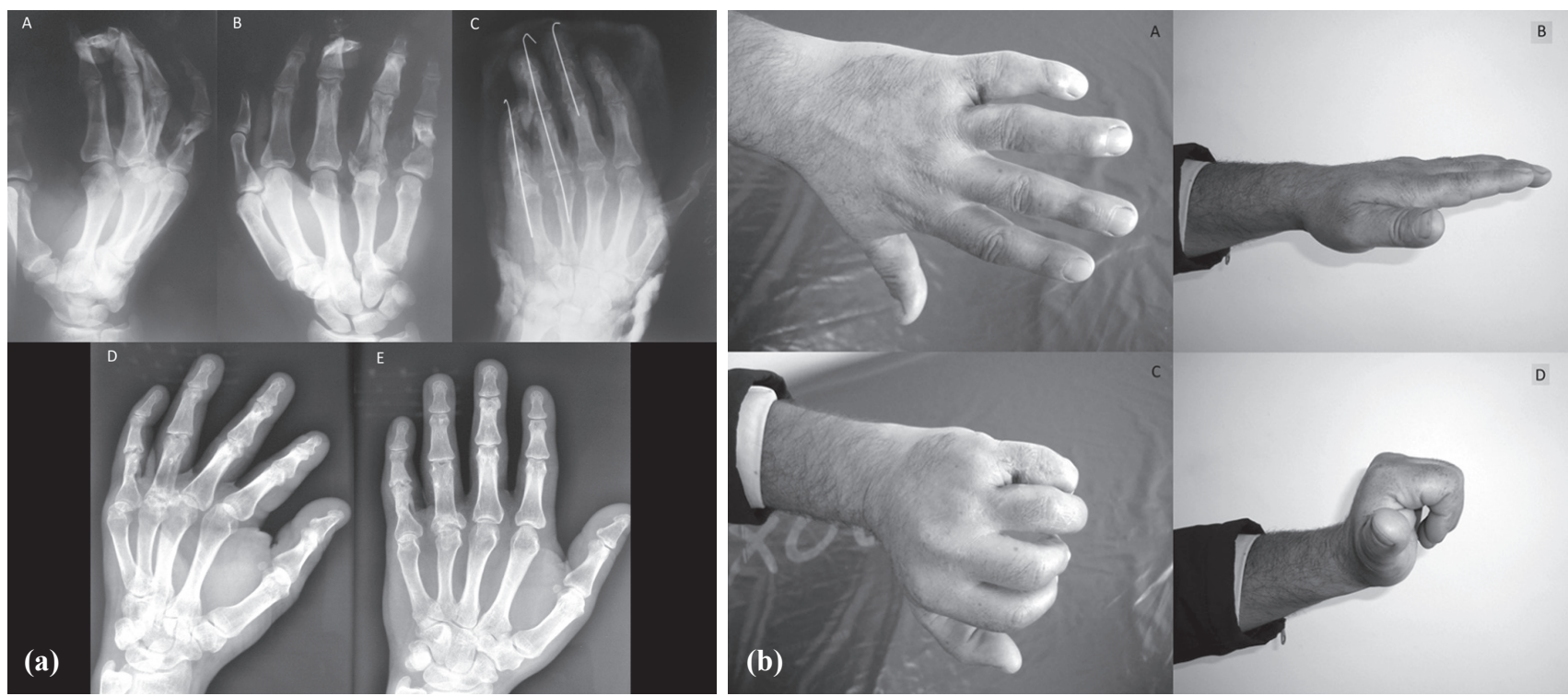

Fig. 4. (a) A comminuted T-fracture of the base and the shaft of the proximal phalanx extending to the MCP joint in the left hand 4th finger; unstable displaced extraarticular proximal phalanx shaft fracture in the 5th finger; and unstable displaced middle phalanx shaft fracture extending to the DIP joint in the 3rd finger. Fractures were treated with K-wires. A second $\mathrm{K}$-wire could be used for further reduction and fixation of the T-fracture of the 4th finger, but its comminuted nature was found to be unsuitable for additional K-wire placement. Good bone healing was observed in the postoperative 2 nd year. A-B: Preoperative anteroposterior and oblique X-ray views. C: Early postoperative anteroposterior X-ray view. D: Late postoperative anteroposterior and oblique X-ray views.

(b) Functional results of the patient with unstable displaced proximal phalanx shaft and base fractures extending to the MCP joint in the left hand 4th finger; unstable displaced extraarticular proximal phalanx shaft fracture in the 5th finger; and unstable displaced middle phalanx shaft fracture extending to the DIP joint in the 3rd finger in the postoperative 2 nd year. A: Minimal angulation at the 5th finger was observed in the dorsal view with no functional impairment. B: No extension deficit was observed. C-D: ROM and TAM evaluations were excellent (TAMs of 4th and 5th fingers were $260^{\circ}$ ). 
of reduction, total active ROM, development of joint contracture, grip strength, and digital grip strength, were assessed. Good or excellent results were obtained in $76 \%$ of fractures (19 of 25). They concluded that transmetacarpal K-wire fixation is a technically simple method of treating unstable PP fractures, and good or excellent results can be obtained in the majority of appropriately selected patients. Similar successful results were reported in different studies as well. ${ }^{[11-13]}$ The data (Tables 1-6) in our study also verified successful usage of K-wire in PP fracture management.

In our cases, we used splint only when the fracture line was stable. In case of unstable fractures, we definitely used K-wire. By following this basic principle, we did not notice any displacement following mobilization in 32 PP fractures. Of 32 fingers, late-term TAM scores were evaluated, and 20 fingers were graded as perfect and 7 fingers as good (Table 3). In long-term follow-ups, the grip strength of the broken finger was compared with that of healthy fingers, and no difference was observed. Results were accepted as successful.

Stanton et al. ${ }^{[2]}$ analyzed 423 hand fractures (metacarpal and phalanx) using X-rays, and demonstrated that 363 of them were extraarticular and 70 were intraarticular fractures. This distribution is similar to that of our cases, which included $22(69 \%)$ extraarticular and 10 (31\%) intraarticular fractures (Table 5).

In our series, mean ROM values of the PIP joint $\left(90^{\circ}\right)$ and IP joint $\left(87.5^{\circ}\right)$ extraarticular fractures were found higher than that of PIP joint $\left(70^{\circ}\right)$ and IP joint $\left(75^{\circ}\right)$ intraarticular fractures, as expected. Mean ROM value of the MCP joint $\left(71^{\circ}\right)$ in extraarticular fractures, however, was the same as that of MCP joint $\left(71^{\circ}\right)$ intraarticular fractures.

ROMs of 29 fingers (91\%) for MCP joint, 15 fingers (47\%) for PIP joint and 7 fingers (100\%) for IP joint were calculated as perfect (Table 1). In other words, the poorest outcome was observed in the PIP joint.

There is a common consensus among many authors that radiographic healing is not correlated well with clinical healing. ${ }^{[1]}$ The average time for clinical union was 5-7 weeks for the middle portion of the PP and up to 10-14 weeks for transverse fractures of the exceedingly hard cortical portion of the middle phalanx. ${ }^{[14]}$ Complete bone healing generally takes about 5 months. Clinical healing, however, occurs in onefourth of this period. In our series, clinical healing occurred between 4-6 weeks.

Among the complications such as malunion, nonunion, loss of movement (tendon adhesion, capsule contraction, crush injury), infection, or tendon rupture, we observed 1 non-union in $32 \mathrm{PP}$ cases. No infection or other complications were observed.
In late-term follow-ups, we did not observe significant angulation or rotation interfering with the function of the finger (Fig. 4a-b). The low complication rate was thought to be related with the sufficient debridement intraoperatively, good reduction of the fragments, stable fixation, close follow-up, and early mobilization of the finger.

We concluded that Kirschner wire fixation is a reliable and technically simple method for treating unstable PP fractures, and results in long-term good or excellent results in appropriately selected patients. In stable PP fractures, it was observed that cast splint provides adequate treatment.

\section{REFERENCES}

1. Dick HM, Carlson EC. Fractures of the fingers and thumb. In: Smith JW, Aston SJ, editors. Grabb and Smith's plastic surgery. Boston: Little, Brown and Company; 1991. p. 909-16.

2. Stanton JS, Dias JJ, Burke FD. Fractures of the tubular bones of the hand. J Hand Surg Eur Vol 2007;32:626-36.

3. Stern PJ. Fractures of the metacarpals and phalanges. In: Green DP, Hotchkiss RN, Pederson WC, editors. Green's operative hand surgery. New York: Churchill Livingstone; 1993. p. 711-71.

4. Koman LA, Coonrad R, Poehling GG. Sprains and dislocations of the fingers and thumb. In: Smith JW, Aston SJ, editors. Grabb and Smith's Plastic Surgery. Boston: Little, Brown and Company; 1991. p. 889-907.

5. Henry MH. Fractures of the proximal phalanx and metacarpals in the hand: preferred methods of stabilization. J Am Acad Orthop Surg 2008; 16:586-95.

6. Kurzen P, Fusetti C, Bonaccio M, Nagy L. Complications after plate fixation of phalangeal fractures. J Trauma 2006;60:841-3.

7. Al-Qattan MM. Closed reduction and percutaneous K-wires versus open reduction and interosseous loop wires for displaced unstable transverse fractures of the shaft of the proximal phalanx of the fingers in industrial workers. J Hand Surg Eur Vol 2008;33:552-6.

8. Sorene ED, Goodwin DR. Non-operative treatment of displaced avulsion fractures of the ulnar base of the proximal phalanx of the thumb. Scand J Plast Reconstr Surg Hand Surg 2003;37:225-7.

9. Horton TC, Hatton M, Davis TR. A prospective randomized controlled study of fixation of long oblique and spiral shaft fractures of the proximal phalanx: closed reduction and percutaneous Kirschner wiring versus open reduction and lag screw fixation. J Hand Surg Br 2003;28:5-9.

10. Elmaraghy MW, Elmaraghy AW, Richards RS, Chinchalkar SJ, Turner R, Roth JH. Transmetacarpal intramedullary Kwire fixation of proximal phalangeal fractures. Ann Plast Surg 1998;41:125-30.

11. Liew KH, Chan BK, Low CO. Metacarpal and proximal phalangeal fractures-fixation with multiple intramedullary Kirschner wires. Hand Surg 2000;5:125-30.

12. Newington DP, Davis TR, Barton NJ. The treatment of dorsal fracture-dislocation of the proximal interphalangeal joint by closed reduction and Kirschner wire fixation: a 16-year follow up. J Hand Surg Br 2001;26:537-40.

13. Hornbach EE, Cohen MS. Closed reduction and percutaneous pinning of fractures of the proximal phalanx. J Hand Surg Br 2001;26:45-9.

14. Moberg E. The use of traction treatment for fractures of phalanges and metacarpals. Acta Chir Scand 1949;99:341-52. 